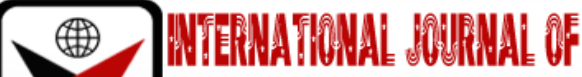

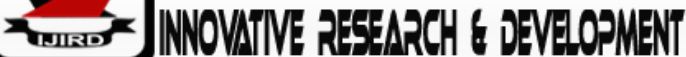

ISSN 2278-0211 (Online)

\section{Proximate Analysis And Heavy Metal Concentration of Solanum Tuberosum (L.) and Ipomea Batatas(L.) Lam Collected from Okokomaiko Market in Ojo Local Government Area in Lagos, Nigeria}

\begin{tabular}{|c|}
\hline Adu, A.A \\
Associate Professor, Department of Botany, \\
Lagos state University. OJO, Lagos, Nigeria \\
Aderinola, O.J \\
Associate Professor, Department of Zoology and Environmental Biology, \\
Lagos State University, Ojo, Lagos Nigeria \\
Avoseh,0 \\
Senior Lecturer, Department of Chemistry, \\
Lagos State University, Ojo, Lagos Nigeria \\
Agoro A.K \\
Post Graduate Student, Department of Botany, \\
Lagos State University, Ojo, Lagos Nigeria
\end{tabular}

\begin{abstract}
:
Ipomeabatat as and Solanumtuberosum are commonly eating in Nigeria because they are rich in mineral content and equally cheap to buy by average Nigerians. However, most of the soils where these products are planted are often affected by heavy metals due to human actions around the farms. Consequently, this study was undertaken to investigate the proximate, mineral and heavy metals contents in some Ipomeabatatas and Solanumtuberosum from market area in Ojo Local Government Area of Lagos state, Nigeria. The collections of tuber samples and the methods of analyses used are those specified in American Public Health Association (APHA), American Water Works Association (AWWA) and Water Environment Federation (WEF). The results showed that there was no significant difference $(p>0.05)$ between Crude protein (CP), Crude fat (CF), Crude fibre (CFB), Ash, and Hydrocyanic acid found in Ipomeabatatas and Solanumtuberosum from the market. However, there was significant difference $(P<0.05)$ in Moisture, Carbohydrate, Sugar, Carotenoid, and Ascorbic acid recorded in Ipomeabatatas and Solanumtuberosum. The values are $(70.960 \pm 0.163,78.955 \pm 0.106 \%)$, (23.985 $\pm 0.148,16.675 \pm 0.163 \%),(8.115 \pm 0.148,1.245 \pm$ $0.276 \%),(5.20 \pm 0.438,0.890 \pm 0.113 \%)$, and $(41.61 \pm 4.373,19.310 \pm 4.568 \%)$ respectively.More so, there were no significant difference ( $p>0.05$ ) between Calcium (Ca), Manganese (Mn), Copper (Cu), Zinc ( $\mathrm{Zn}$ ), Chromium (Cr), and Cobalt (C), recorded in Ipomeabatatas and Solanumtuberosum from the market. All the values of heavy metal recorded were within the WHO permissible limit. On the contrary, there were significant difference $(\mathrm{P}<0.05)$ in Magnesium $(\mathrm{Mg})$, Sodium (Na), Potassium (K), Iron $(\mathrm{Pb})$, Phosphorus (P), recorded in Ipomeabatatas and Solanumtuberosum. The values are $(81.92 \pm 0.93,131.35 \pm 0.59 \mathrm{mg} / 100 \mathrm{~g})$, $(10.96 \pm 0.87,323.18 \pm 2.94 \mathrm{mg} / 100 \mathrm{~g}), \quad(1138.39 \pm 6.37,209.93 \pm 0.94 \mathrm{mg} / 100 \mathrm{~g}), \quad(0.53 \pm 0.06$, $4.0 \pm S 0.10 \mathrm{mg} / 100 \mathrm{~g}),(167.95 \pm 2.07,210.14 \pm 1.02 \mathrm{mg} / 100 \mathrm{~g})$. It can be concluded that the two plant species examined are very rich in nutrient however the heavy metal contents are within the acceptable limit but activities that may further increase their values should be discouraged to avoid bioaccumulation.
\end{abstract}

Keywords: Ipomeabatatas, Solanumtuberosum, Lagos, Heavy metal, Proximate analysis

\section{Introduction}

Ipomeabatatas (Sweet potatoes) and Solanumtu berosum (Irish potatoes)are an exceptionally essential crop in several parts of the world, being produced in more than 100 countries.The mineral content and heavy metals contents in theses food crops need to be monitored in tropical countries, especially in Africa where the population consumes mainly 
locally grown food due to poverty. Consequently, it requires the acquisition of large sets of fundamental data on the occurrence and distribution of a variety of bio elements in soils and food.

Rapid growth in industrial development has been accompanied throughout the world by the extraction and distribution of mineral substances from their natural developments (Sing, 2001).Meanwhile, the consumption of this food crop especiallyIpomoea batatasjust increased among the larger Nigeria population due to increasing poverty ravaging the common man because it is cheap. They provide physiological energy reserves, thus, their contribution to the population diet cannot be neglected,(McCance and Widdowson's, 2002, Rose, 2010).

Heavy metal is one of the serious environmental problems limiting plant productivity and threatening human health (Luptaka et. al., 2002, Verma and Dubey, 2003. Kadukovaet.al., 2006). Inputs of heavy metals to agricultural soil can occur from a variety of sources. These include the application of bio-solids, fertilizers, livestock manure, agrochemicals and irrigation water and from atmospheric deposition (Mc Laugh S 1999; Gray et. al., 2003).

Among the substances that contribute anthropogenically to pollution of the biosphere, trace elements are the most toxic. Lead, Zinc and Cadmium are toxic metals of increasing environmental concern as they enter the food chain in significant amount (Luptakaet. al., 2002; Verma and Dubey, 2003; kadookovaet. al., 2006). There is therefore, the need for studies to establish the level of these heavy metals in the Solanumtuberosum and Ipomeabatatas.

\section{Materials and Methods}

Samples of Ipomeabatatas and Solanumtuberosum were collected from Okokomaiko market at Ojo Local Government Area of Lagos,Nigeria between 20 October and 20 December 2020 and washed, first with running water to remove the soil particles with distilled water, preserved by storage in clean polythene bag, at $4^{\circ} \mathrm{C}$, until analyzed.

Before performing the analyses, the residual moisture was evaporated at room temperature. The samples were ground with a mortar prior to the analysis. All glassware and plastic ware used for analysis were washed with $5 \% \mathrm{v} / \mathrm{v}$ nitric acid and rinsed with distilled water prior to use.

Ipomoea batatas and Solanumtuberosum were taken for the study. The proximate analysis viz., estimation of moisture, ash, crude protein, crude fat, carbohydrate, crude fiber along with total reducing sugars and $ß$ carotene content were carried out according to the stipulated procedures laid down for analysis (AOAC,2005).

Determination of moisture was carried out by oven method, while ash content was determined by the dry ash method in a muffle furnace while protein determination was by Kjeldahl method. Total reducing sugars and ßcarotene were determined by UV Spectrophotometric method, crude fibre was determined by calcinations method. The results thus obtained were statistically analyzed using SPSS version 23

\subsection{Preparation of Wet Digestion Acid}

$\mathrm{HNO}_{3}, \mathrm{HCLO}_{4}$ and $\mathrm{H}_{2} \mathrm{SO}_{4}$ were mixed together in the ratio of 30:4:1 in order to form the wet digestion acid mixture.

\subsection{Procedure for Digestion}

$5.0 \mathrm{~g}$ of each of the samples were accurately weighed and transferred into digestion tubes, $30 \mathrm{ml}$ of the wet digestion acid mixture were added to each sample in the digestion tubes, the digestion tube containing acid mixture was placed on the digestion apparatus, which was allowed to digest for about $1 \frac{1}{2}$ hours until a clear solution is obtained. The end of the digestion was marked by the evolution of a white dense fume of percholoric acid (HCLO $0_{4}$ ) and the reduction of volume to about $5 \mathrm{ml}$, and then the digestion process was discontinued. The digest was allowed to cool and transferred quantitatively in a $100 \mathrm{~cm} 3$ volumetric flasks, then was made up to the mark with distilled water. The digest of each sample was transferred into different well stopper rubber container which was made ready for atomic absorption spectroscopic analysis.

\section{Result}

\subsection{Proximate Concentration InipomeaBatatas and SolanumTuberosum}

Table 1 showed the proximate concentration in Ipomeabatatas and Solanumtuberosum Collected from market (Okokomaiko) in Ojo, Lagos State, Nigeria.There was no significant difference ( $\mathrm{p}>0.05$ ) between Crude protein (Cp), Crude fat (Cf), Crude fibre (Cf), Ash, and Hydrocyanic acid found in Ipomeabatatas and Solanumtuberosumfrom the market. The values are $(2.745 \pm 0.177,1.730 \pm 0.085 \%),(0.550 \pm 0.280,0.105 \pm 0.021 \%),(0.510 \pm 0.057,1.380 \pm 0.085 \%),(1.255 \pm 0.106$, $1.170 \pm 0.057 \%),(0.965 \pm 0.120,1.505 \pm 0.474 \%)$. However, there was significant difference $(\mathrm{p}<0.05)$ in $M o i s t u r e$, Carbohydrate, Sugar, Carotenoid, and Ascorbic acid recorded in Ipomeabatatas and Solanumtuberosum. The values are $(70.960 \pm 0.163,78.955 \pm 0.106 \%),(23.985 \pm 0.148,16.675 \pm 0.163 \%),(8.115 \pm 0.148,1.245 \pm 0.276 \%),(5.20 \pm 0.438$, $0.890 \pm 0.113 \%),(41.615 \pm 4.373,19.310 \pm 4.568 \%)$.

\subsection{Heavy Metal Concentration in IpomeaBatatas and SolanumTuberosum}

Table 2showed the heavy metal Concentration in Ipomeabatatas and Solanumtuberosum Collected from market (Okoko) in ojo, Lagos state, Nigeria. There was no significant difference ( $\mathrm{p}>0.05$ ) between Calcium (Ca), Manganese (Mn), Copper (Cu), Zinc (Zn), Chromium (Cr), and Cobalt (C), recorded in Ipomeabatatas and Solanumtuberosum from the market. The values are $(44.03 \pm 0.06,42.50 \pm 0.52 \mathrm{mg} / 100 \mathrm{~g}),(2.14 \pm 0.10,2.98 \pm 0.00 \mathrm{mg} / 100 \mathrm{~g}),(0.60 \pm 0.05,1.04 \pm$ $0.05 \mathrm{mg} / 100 \mathrm{~g}),(3.50 \pm 0.53,3.62 \pm 0.40 \mathrm{mg} / 100 \mathrm{~g}),(0.0056 \pm 0.0022,0.0052 \pm 0.0011 \mathrm{mg} / 100 \mathrm{~g}),(1.1400 \pm 0.050,0.0002 \pm$ $0.0002 \mathrm{mg} / 100 \mathrm{~g})$. However, there was significant difference $(\mathrm{p}<0.05)$ inMagnesium $(\mathrm{Mg})$, Sodium (Na), Potassium (K), Iron $(\mathrm{Pb})$, Phosphorus (P), recorded in Ipomeabatatas and Solanumtuberosum. The values are (81.92 \pm 0.93 , 
$131.35 \pm 0.59 \mathrm{mg} / 100 \mathrm{~g}),(10.96 \pm 0.87,323.18 \pm 2.94 \mathrm{mg} / 100 \mathrm{~g}), \quad(1138.39 \pm 6.37, \quad 209.93 \pm 0.94 \mathrm{mg} / 100 \mathrm{~g}), \quad(0.53 \pm 0.06$, $4.0 \pm 0.10 \mathrm{mg} / 100 \mathrm{~g}),(167.95 \pm 2.07,210.14 \pm \mathrm{s} 1.02 \mathrm{mg} / 100 \mathrm{~g})$

\begin{tabular}{|c|c|c|}
\hline Parameter & IpomeaBatatas & SolanumTuberosum \\
\hline Moisture (\%) & $70.960 \pm 0.163^{a}$ & $78.955 \pm 0.106^{b}$ \\
\hline Crude protein (\%) & $2.745 \pm 0.177^{\mathrm{a}}$ & $1.730 \pm 0.085^{\mathrm{a}}$ \\
\hline Crude fat (\%) & $0.550 \pm 0.280^{\mathrm{a}}$ & $0.105 \pm 0.021^{\mathrm{a}}$ \\
\hline Crude fibre (\%) & $0.510 \pm 0.057^{\mathrm{a}}$ & $1.380 \pm 0.085^{\mathrm{a}}$ \\
\hline Ash (\%) & $1.255 \pm 0.106^{\mathrm{a}}$ & $1.170 \pm 0.057^{\mathrm{a}}$ \\
\hline Carbohydrate (\%) & $23.985 \pm 0.148^{\mathrm{a}}$ & $16.675 \pm 0.163^{b}$ \\
\hline Sugar (Brix) & $8.115 \pm 0.148^{\mathrm{a}}$ & $1.245 \pm 0.276^{\mathrm{b}}$ \\
\hline Carotenoid (mg/100g) & $5.200 \pm 0.438^{\mathrm{a}}$ & $0.890 \pm 0.113^{\mathrm{b}}$ \\
\hline Ascorbic acid(mg/100g) & $41.615 \pm 4.373^{\mathrm{a}}$ & $19.310 \pm 4.568^{\mathrm{b}}$ \\
\hline Hydrocyanic acid(mg/100g) & $0.965 \pm 0.120^{\mathrm{a}}$ & $1.505 \pm 0.474^{\mathrm{a}}$ \\
\hline
\end{tabular}

Table 1: Proximate Composition of IpomeaBatatas and SolanumTuberosum

Mean $\pm S D$ Value with Different Superscript across the Row =Significant Difference $(P<0.05)$

\begin{tabular}{|c|c|c|}
\hline Heavy Metals(mg/100g) & IpomeaBatatas & SolanumTuberosum \\
\hline Calcium & $44.03 \pm 0.06^{\mathrm{a}}$ & $42.50 \pm 0.52^{\mathrm{a}}$ \\
\hline Magnesium & $81.92 \pm 0.93^{a}$ & $131.35 \pm 0.59 \mathrm{~b}$ \\
\hline Sodium & $10.96 \pm 0.87^{a}$ & $323.18 \pm 2.94^{b}$ \\
\hline Potassium & $1138.39 \pm 6.37 \mathrm{a}$ & $209.93 \pm 0.94 b$ \\
\hline Iron & $0.53 \pm 0.06^{\mathrm{a}}$ & $4.08 \pm 0.10^{b}$ \\
\hline Manganese & $2.14 \pm 0.10^{\mathrm{a}}$ & $2.98 \pm 0.00^{\mathrm{a}}$ \\
\hline Copper & $0.60 \pm 0.05^{\mathrm{a}}$ & $1.04 \pm 0.05^{\mathrm{a}}$ \\
\hline Phosphorus & $167.95 \pm 2.07^{\mathrm{a}}$ & $210.14 \pm 1.02^{\mathrm{b}}$ \\
\hline Zinc & $3.50 \pm 0.53^{a}$ & $3.62 \pm 0.40^{\mathrm{a}}$ \\
\hline Selenium & ND & ND \\
\hline Lead & ND & ND \\
\hline Chromium & $0.0056 \pm 0.0022^{\mathrm{a}}$ & $0.0052 \pm 0.0011^{\mathrm{a}}$ \\
\hline Cobalt & $1.1400 \pm 0.050^{\mathrm{a}}$ & $0.0002 \pm 0.0002^{\mathrm{a}}$ \\
\hline Nickel & ND & ND \\
\hline Arsenic & ND & ND \\
\hline Cadmium & ND & ND \\
\hline
\end{tabular}

Table 2: Heavy Metals Concentration in IpomeaBatatas and SolanumTuberosum $N D=$ Not Detected. Mean \pm SD with Different Values in the Row = Significant Difference $(P<0.05)$

\subsection{Frequency Distribution of Proximate Concentration in Ipomea Batatas and Solanum Uberosum}

The frequency of proximate concentration (Moisture, Crude protein, Crude fat, Crudefibre, Ash, Carbonhydrate, Sugar, Carotenoids, Ascorbic acid, Hdrocyanic acid) in Ipomeabatatas and are presented in figure 1.

\subsection{Frequency Distribution of the Heavy Metals in IpomeaBatatas and SolanumTuberosum}

The frequency of heavy metals ( $\mathrm{Ca}, \mathrm{Mg}, \mathrm{Na}, \mathrm{K}, \mathrm{Fe}, \mathrm{As} \mathrm{Cd}, \mathrm{Mn}, \mathrm{Cu}, \mathrm{Zn}, \mathrm{Cr}, \mathrm{C}$,)in Ipomeabatatas and Solanumtuberosum from the market presented in figure 2

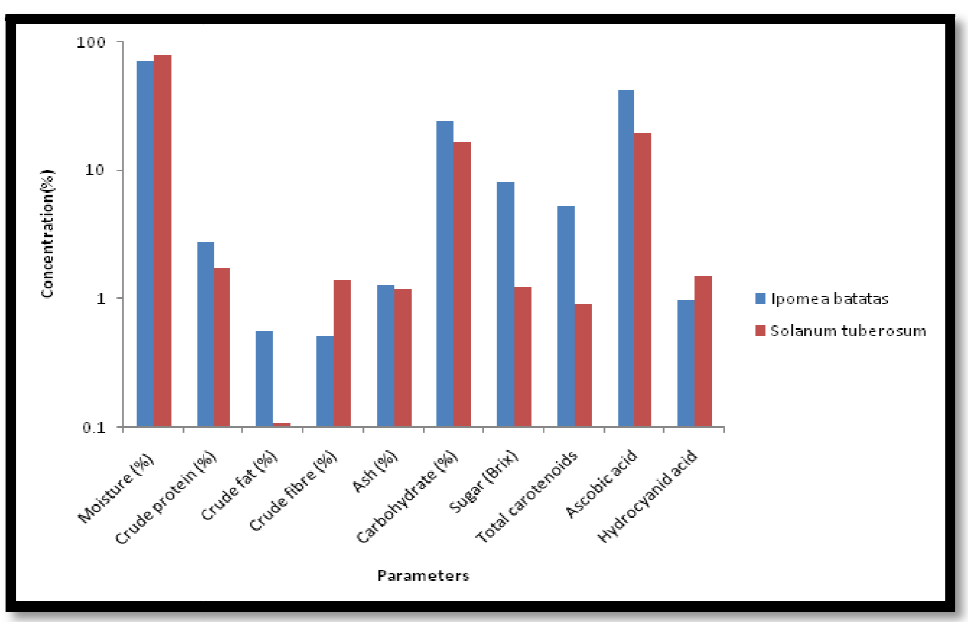

Figure 1: Frequency Distribution of Proximate Concentration in Ipomea Batatas and SolanumTuberosum 


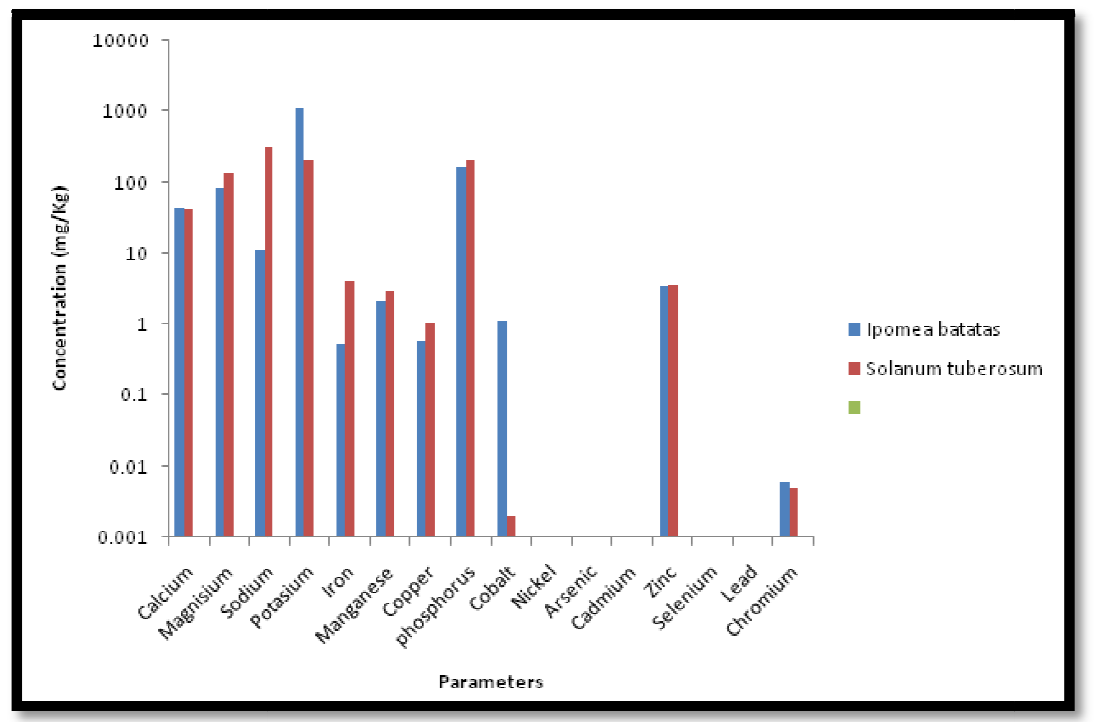

Figure 2: Frequency Distribution of the Heavy Metals in Ipomea Batatasand SolanumTuberosum

\subsubsection{Moisture Content (\%)}

The moisture content Ipomeabatatas (sweet potato) takes for the study is high with the value of $70.955 \pm 0.163$ and is also very high is Solanumtuberosum (Irish potato) with the value of $78.955 \pm 0.106$. The differences in the moisture content among the Ipomeabatatas and Solanum tuberosum can be attributed to the difference in the genetic composition and also the agricultural practices. In common with other roots and tubers, the Ipomeabatatas has a high moisture content resulting in relatively low dry matter content but varies widely depending on factors such as cultivars, location, climate, day length, soil pest diseases and cultivation practices.

\subsubsection{CrudeProtein(\%)}

The crude protein content in Ipomeabatatas is very high with the value of $2.745 \pm 0.177$ and is low in Solanumtu berosum with the values of $1.730 \pm 0.085$. Both comparing the both under the (\%), the two values are still below $50 \%$. Protein content in the diets $\mathrm{f}$ low-income groups in developing countries like Nigeria is derived mostly from food vegetables origin.

\subsubsection{Crude Fibre}

In the present study, fibre in Ipomeabatatas is very low with the value of $0.510 \pm 0.57$ and is high in Solanumtuberosum with the value of $1.380 \pm 0.085$. Under the (\%) both the value for Ipomeabatatas and Solanumtuberosum are still low which are below 50\%. This study recorded lesser amount than the above quoted literature and therefore indicate to be a poor source of dietary fibre.

\subsubsection{Ash (\%)}

The ash content in Ipomeabatatas is high with the value of $1.255 \pm 0.106$ and is low in Solanumtuberosum with the value of $1.170 \pm 0.057$. The two values gotten are still low which are still below $50 \%$. The amount of minerals furnished in $100 \mathrm{~g}$ is small for all the minerals, with the possible exception of potassium that furnished about $11.4 \%$ or $18 \%$ of the RDA.

\subsubsection{Sugar (Brix)}

Sucrose is the most abundant sugar in raw Ipomeabatatas and Solanumtuberosum with smaller amount of glucose and fructose. In present study, the total sugar in the Ipomeabatatas were found to be high with the value of $8.115 \pm 0.148$ and is low in Solanumtu berosum with the value of $1.245 \pm 0.276$.The sugar content in the present study isstill within the ranges quoted.

\subsection{Total Carotenoid Content}

The total carotenoids in Ipomeabatatas is high with the value of $5.200^{+}-0.438$ and is relatively low in Solanumtuberosum with the value of $0.890^{+}-0.113$. Based on the \%, the two values gotten are still below $50 \%$. The reason has to do with the differences with the species of Ipomeabatatas and Solanumtuberosum.

\subsubsection{Zinc}

The result of $\mathrm{Zn}$ in Ipomeabatatas was the lowest with the mean value of $\left(3.500^{+} .0 .750 \mathrm{mg} / \mathrm{kg}\right.$.) and the highest in Solanumtuberosum with the mean value $\left(3.615^{+} .0 .573 \mathrm{mg} / \mathrm{kg}\right)$. The two values gotten are higher than the WHO standard which is $(0.60 \mathrm{mg} / \mathrm{kg})$ and the species are dangerous to consumed because of high level of zinc. 


\subsubsection{Copper}

$\mathrm{Cu}$ was the lowest in Ipomeabatatas with the mean value of $\left(0.600^{+} .0 .071 \mathrm{mg} / \mathrm{kg}\right)$ and the highest in Solanumtuberosumwith the mean value of $\left(1.040^{+}-0.071 \mathrm{mg} / \mathrm{kg}\right)$. The two values gotten are lower than the WHO standard value $(1.30 \mathrm{mg} / \mathrm{kg})$ which mean is safe to consumed the food that have low level of copper.

\subsubsection{Chromium}

The result of Chromium with the mean value of $\left(0.006^{+} .0 .003 \mathrm{mg} / \mathrm{kg}\right)$ was the highest in Ipomeabatatas but the lowest in Solanumtuberosum with the mean value of $\left(0.005^{+}-0.001 \mathrm{mg} / \mathrm{kg}\right)$. Comparing the two values to the WHO standard $(1.30 \mathrm{mg} / \mathrm{kg})$, there are still below the WHO standard which are within the safe limit.

The values of Lead (Pb), Cadmium (Cd), Nickel (Ni), Arsenic (As), are not detected in the analysis.

\section{Discussion and Conclusion}

The result of zinc with the mean value of $(3.500+0.750 \mathrm{mg})$ was the lowest in Ipomeabatatasbut the highest in Solanumtuberosumwith the mean value of $(3.615+0.5573 \mathrm{mg} / \mathrm{kg})$. According to WHO (1996), the permissible value for zinc $(\mathrm{Zn})$ is $(0.60 \mathrm{mg} / \mathrm{kg})$. Comparing the two values gotten for Ipomeabatatas and Solanumtuberosum to the WHO standard $(0.60 \mathrm{mg} / \mathrm{kg})$, the values are higher than the permissible values. Ostrowska et al., (2004), got the mean value of 2.52+ $0.33 \mathrm{~kg} / \mathrm{mg}$ Colocasiaesculenta (cocoyam) and mean value of $1.08+0.05 \mathrm{~kg} / \mathrm{mg}$ in Solanumtuberosum (potato) which are higher than the WHO permissible limit. High level of zinc may be because of zinc content in potato tubers affected by unlimited mobility of zinc in the phloem. (whiteet al., 2012).

Copper content in Ipomeabatatas has low value of $0.600+0.071 \mathrm{mg} / \mathrm{kg}$ and high in Solanumtuberosum with the mean value of $1.040+0 .-071 \mathrm{mg} / \mathrm{kg}$. Comparing the two values is lower than the WHO standard value (10mg/kg). Which means it is safe to consume. (Ostruwska et al., 2004), got the mean value of $1.24+0.15 \mathrm{~kg} / \mathrm{mg}$ in Colocasiaesculenta and mean value of $0.23+0.04 \mathrm{~kg} / \mathrm{mg}$ in Solanumtuberosum which is lower than the WHO permissible limit. For now, this particular plant is safe but continuous accumulation can cause a future damage to consumer.

Concentration of chromium in Ipomeabatatas ranged from $(0.005 \pm 0.003 \mathrm{mg} / \mathrm{kg})$ which is higher and lower in Solaniumtuberosum with the mean value of $(0.005 \pm 0.001 \mathrm{mg} / \mathrm{kg})$. The WHO permissible value is $(1.30 \mathrm{mg} / \mathrm{kg})$. Comparing the two values to WHO standard, the values are lower than the WHO permissible limit which is safe. According to Ostraowska et al., (2014) in his analysis got the mean value $5.17 \pm 0.16 \mathrm{mg} / \mathrm{kg}$ in Solanumtuberosum and the mean value of $2.53 \pm 0.028 \mathrm{mg} / \mathrm{kg}$ in Colocasiaesculenta. The result of Ostrowska et al., is higher than the WHO standard (1996) maybe as a result of different kinds of chromium that differ in their effects and upon which they enter air, water and the soil $\mathrm{cr}^{3+}$ and $\mathrm{Cr}^{6+}$ form through natural processes and human activities. Chromium is not essential for plant growth; it was not detected in some plant sites due to the fact that uptake of $\mathrm{Cr}$ by plant shoot is generally low (Hoffman and Curnow (1973).

Iron has the mean value of $0.530 \pm 0.085 \mathrm{mg} / \mathrm{kg}$ in Ipomeabatatas which is low and the mean value of $4.075 \pm 0.134 \mathrm{mg} / \mathrm{kg}$ in Solanumtuberosumwhich is high. The values of Ipomeabatatas and Solanumtuberosum are still lower than the normal WHO/FAO standard limit which is $(20 \mathrm{mg} / \mathrm{kg})$. Ostrowski et al., 2004 got the mean value of $13.87 \pm 0.48 \mathrm{mg} / \mathrm{kg}$ in Colocasiaesculentawhich is lower than the WHO permissible limit which is safe for consumption. The result is still within the permissible limit but with time could accumulate and cause havoc.

The result of manganese in Ipomeabatatas is low with the mean value of $2.140 \pm 1.141 \mathrm{mg} / \mathrm{kg}$ and has the mean value of $2.975 \pm 0.007 \mathrm{mg} / \mathrm{kg}$ in Solanumtuberosum which is high. The WHO permissible limit is $200 \mathrm{mg} / \mathrm{kg}$. Comparing the result of Ipomeabatatas and Solanumtuberosum to the WHO standard, the result is very low comparing to the WHO standard. According to Ostrowskaet al., 2004. On his research on his research on manganese in Solanumtuberosumgot the mean value of $89.68 \pm 1.03 \mathrm{mg} / \mathrm{kg}$ and the mean value of $128.35 \pm 1.54 \mathrm{mg} / \mathrm{kg}$ in Colocasiaesculenta which is lower than the WHO permissible limit. For now, the value is below but continuous consumption of that plant will bring about bioaccumulation and can degenerate into a high risk.

\section{Conclusion}

The study has shown that Ipomeabatatas and Solanumtuberosum are rich in nutrient. The Moisture, Carbohydrate, Sugar, Carotenoids, and Ascorbic acid are significantly higher in Solanumtuberosum than Ipomeabatatas. On the other hand, higher heavy metal concentrations were recorded in Solanumtuberosum. The presence of metals in this plant is an indication that the soil is contaminated with metals; however, the content in the plant is within recorded limit.

\section{References}

i. AOAC (2005) Official Method of Analysis, 16th edition Association of Official Analytical Chemist, Washington DC.

ii. Gray, W.D., Schoelles, M.J., Brings jord, S.A., Burrows, K., \& Colder, B. (2003). Sage five powerful ideals for studying and transforming the intelligent analyst's task environment, 47th annual Conference of the Human factors and Ergonomics society (pp. 1019-1023).

iii. Hoffman Dustin, Steve McQueen, Papilon, 1973 Solar Productions File Reference.

iv. Kadukova, j., E. Manousaki, and Kalogerakis (2006). Lead and Cadmium accumulation from contaminated soils by Nerium Oleander. ActametallurdicaSlovaca 12: 181- 187.

v. Luptak A, Ferre D' Amare AR, Zhou K, Zilm KW, Doudna JA. Direct PK (a) a genomic hepatitis delta virus ribozyme (2002). Amchemsoc. 123(35): 8447-52.

vi. McCance and Widdowson's The Composition of Foods, Sixth summary edition. Food Standards Agency. Cambridge: Royal Society of Chemistry. (2002). 
vii. OSTROWSKA, A., ZIÓŁKOWSKA, A. and KŁOSIEWICZ-LATOSZEK, L. 2004. Assessment of mineral elements in Warsaw medical students' daily food rations. New Med. 7(2), 45- 47.

viii. Sing, B. (2001). Heavy metals in soils: Source, chemicals Reactions and Forms. In D. Smith, S. fityus, \& m. Allman (Eds, pp. 77-93), Geo Environment: proceeding of the 2nd Australia and New Zealand Conference on Environmental Geotechnis: New Castle, .LNew South Wales.

ix. Verma S, Dubey RS (2003) Lead toxicity Induces lipid per- oxidation and alters the activities oof antioxidant enzymes in growing rice plants. Plant Soil. 164: 645- 655.

x. White, I. R., Barrett, J. K., Jackson, D., and Higgins, J (2012). Consistency and Inconsistence in network metal analysis: Model estimation using multivariate meta -regression.

xi. World Health Organization (WHO), (1996) permissible Limits of Heavy Metals in soil and plants, World Health Organisation, Genrva, Switzerland. 